\title{
ABE KŌBŌ - MIĘDZY MODERNIZMEM A POSTMODERNIZMEM. ROZWAŻANIA WOKÓŁ POWIEŚCI KANGUROWY NOTATNIK
}

\author{
MiKOŁAJ MELANOWICZ ${ }^{1}$ \\ (Uniwersytet Warszawski)
}

\begin{abstract}
Słowa kluczowe: Abe Kōbō - szkoła powojenna - Murakami - modernizm postmodernizm - Kangarū noto
\end{abstract}

Key words: Abe Kōbō - postwar school - Murakami - modernism - postmodernism Kangarū noto

\begin{abstract}
Abstrakt: Mikołaj Melanowicz. ABE KŌBŌ - MIĘDZY MODERNIZMEM A POSTMODERNIZMEM. ROZWAŻANIA WOKÓも POWIEŚCI KANGUROWY NOTATNIK. PORÓWNANIA 18, 2016. T. XVIII. S. 173-182. ISSN 1733-165X. Przypominając polskim czytelnikom znaczenie twórczości Abe Kōbō (1924-1993) w literaturze japońskiej, pisarza nieżyjącego od ponad dwudziestu lat, autor artykułu formułuje propozycję kategoryzacji jego powieści, opowiadań i dramatów. Wykazuje, że w niemal całej twórczości Abe posługiwał się konwencją charakterystyczną dla modernizmu europejskiego. Natomiast w ostatniej powieści Kangarū nōto (Kangurowy notatnik, 1991), analizowanej szczegółowo w artykule, posłużył się absurdalnymi toposami, fragmentaryzacją bohatera, hybrydyzacją itp. chwytami europejskiej i amerykańskiej powieści postmodernistycznej. Chociaż wiele z tych technik stosował sporadycznie we wcześniejszych utworach, to w strukturze świata przedstawionego i bohatera Kangurowego notatniku odnajdujemy właściwie ich sumę. Bezimienny bohater tej powieści, skierowany przez lekarza do ciepłych źródeł z powodu tajemniczej choroby, polegającej na wyrastaniu rzepy na goleniu, odbywa ostatnią podróż podziemnymi korytarzami w nieznane.
\end{abstract}

Abstract: Mikołaj Melanowicz. ABE KŌBŌ - BETWEEN MODERNISM AND POSTMODERNISM. REFLECTIONS ON THE NOVEL KANGAROO NOTEBOOK. COMPARISONS 18, 2016. Vol. XVIII. P. 173-182. ISSN 1733-165X. While reminding Polish readers of the importance of the

${ }^{1}$ E-mail Address: mikolaj@melanowicz.com 
work of Abe Kōbō (1924-1993), a writer who passed away over twenty years ago, to Japanese literature, the author of this paper puts forward a proposal for the categorisation of Abe's novels, stories and dramas. The author demonstrates that throughout his oeuvre, Abe used a convention typical of European Modernism. However, in his last novel, Kangarū nōto (Kangaroo notebook, 1991), which has been analysed in greater detail in this paper, the writer employed the topos of the absurd, fragmentation of the main character, and hybridisation i.e. literary devices used by the European and American Postmodern novel. Although many of those techniques had sporadically appeared in his earlier works, the structure of the fictional world and the protagonist of the Kangaroo notebook contains a sum of those devices. The nameless hero of the novel, afflicted by a mysterious disease that causes radish sprouts to grow on his shin, is advised by a doctor to travel to hot springs, and embarks on his last journey that takes him through underground corridors into the unknown.

Przedstawiając na wstępie znaczenie twórczości Abe Kōbō (1924-1993) w literaturze japońskiej, autor artykułu twierdzi, że w powieściach, opowiadaniach i dramatach pisarz ten posługiwał się konwencją charakterystyczną dla modernizmu europejskiego. Natomiast w Kangarū nōto (Kangurowy notatnik, 1991), to znaczy w ostatniej powieści, opublikowanej za życia, posłużył się absurdalnymi toposami, fragmentaryzacją eskapistycznego bohatera, hybrydyzacją i innymi chwytami europejskiej i amerykańskiej powieści postmodernistycznej. Wiele $\mathrm{z}$ tych technik stosował sporadycznie we wcześniejszych utworach, poczynając od opowiadania Tenshi (Anioł), odnalezionego dopiero w 2012 roku.

\section{Abe Kōbō i „szkoła powojenna”}

Minęło dwadzieścia lat od śmierci Abe Kōbō, autora Kobiety z wydm (Suna onna, 1962), w Polsce opublikowanej w 1968 roku i kilkakrotnie wznawianej. W tym okresie zaszły poważne zmiany w sytuacji literatury japońskiej, podobnie jak w życiu Japończyków. W Japonii popularna już wtedy była twórczość Murakamich: Harukiego (ur.1949) i Ryū (ur. 1952). Kończył się też okres dominacji modernistów, wśród których największą renomą - zwłaszcza za granicą - cieszył się Abe. Jednocześnie następował odwrót od ambitnych poszukiwań członków tak zwanej „,szkoły powojennej" (jap. sengoha), która wprawdzie rozsypała się przed wielu laty, a jej genialni twórcy w ciągu kolejnych dziesięcioleci decydowali o wielkości japońskiej powieści. Nie żyli już pisarze dwu pokoleń tego ugrupowania: Mishima Yukio (1925-1970), Ōoka Shōhei (1909-1988), Shimao Toshio (1917-1986), Inoue Yasushi (1907-1991), Noma Hiroshi (1919-1991), a kilka lat później zmarł również Endō Shūsaku (1923-1996), wybitny i popularny przedstawiciel trzeciego pokolenia powojennego, zwanego "trzecimi nowymi” (jap. daisan no shinjin). 


\section{Popularny tylko Murakami Haruki?}

Wraz z rozpoczęciem nowego tysiąclecia o japońskiej literaturze znów przypomnieli sobie czytelnicy za granica, ale stało się to tylko dzięki Murakamiemu Harukiemu. Można zatem powiedzieć, że dzięki temu pisarzowi pod koniec XX wieku powieść odzyskuje masowego czytelnika. Pierwszym symptomem okazała się popularność Norwegian Wood (Noruuei no mori, 1987), której sprzedaż w Japonii w 1988 roku przekroczyła osiem milionów egzemplarzy. W wysokich nakładach wydano również Kronikę ptaka nakręcacza (Nejimakidori kuronikuru, 1994) czy Kafkę nad morzem (Umibe no kafuka, 2002), jak również 1Q84 (2009-2010) - zapewne najdłuższą powieść Murakamiego. Na początku kwietnia 2013 roku Murakami znów zaskoczył nową powieścią o prozaicznym tytule Shikisai o motanai Tazaki Tsukuru to, kare no junrei no toshi (Bezbarwny Tazaki Tsukuru i lata jego pielgrzymstwa, 2013), ponieważ po kilku dniach od rozpoczęcia sprzedaży 12 kwietnia wydrukowano milion egzemplarzy.

W cieniu Murakamiego H. pozostają inni japońscy twórcy, jak na przykład Murakami Ryū, powieściopisarz, nowelista, eseista, scenarzysta filmowy, znany przede wszystkim jako autor powieści Kagirinaku tōmei ni chikai burū (Bezgranicznie prawie przeźroczysty błękit, 1976) i Dzieci ze schowka (Koin rokkā bēbizu, 1980).

Odrębny nurt stanowi twórczość kontynuatorek joryū bungaku, to znaczy „literatury kobiet", wyróżnianych również prestiżowymi nagrodami: imienia Akutagawy (Ogawa Yōko - ur. 1962, Tawada Yōko - ur. 1960, Kawakami Hiromi ur. 1958, Kanehara Hitomi - ur. 1983, Wataya Risa - ur. 1984) i imienia Naokiego (Takamura Kaoru - ur. 1953, Miyabe Miyuki - ur. 1960, Ekuni Kaori - ur. 1964), Kirino Natsuo - ur. 1951).

W tym też okresie, to znaczy od lat 90 . XX wieku, zaobserwowano malejące zainteresowanie literaturą awangardową i modernistyczną. Dotyczyło to nie tylko powieści wspomnianych pisarzy nieżyjących, lecz także wciąż aktywnego Ōe Kenzaburō (ur.1935), który po samobójczej śmierci szwagra, reżysera filmowego, Itamiego Jūzō (1933-1997), wrócił do pisania powieści i opublikował kilka wybitnych dzieł, takich jak: Uchügaeri (Salto, 1999), Torikaeko - Chenjiringu (Odmieniec, 2000), Uregao no dōji (Dziecię o smętnym obliczu, 2002), Suishi (Śmierć w wodzie, 2009) i Bannen yōshiki shū (Zbiór stylów z ostatnich lat, 2013).

\section{Powrót zainteresowania autorem Kobiety $z$ wydm?}

W ostatnich latach pojawiły się pewne oznaki odradzania się zainteresowania twórczością Abe, czego dowodem jest internetowe pismo pt. „Mogura Tsūshin” (Wiadomości Kreta) redagowane przez miłośników literatury Abe. Natomiast wy- 
dawnictwo Shinchōsha opublikowało książkę Abe Kōbō den (Kronika Abe Kōbō, 2011) autorstwa córki pisarza, lekarki Neri, która ujawniła wiele nieznanych wcześniej faktów z życia sławnego ojca, a wydawnictwo Kōdansha - Abe Kōbō to watashi (Abe Kōbō i ja, 2013), Yamaguchi Karin, aktorki i przyjaciółki pisarza. Ważnym wydarzeniem było również odnalezienie listów Abe $^{2}$ i wspomnianego już, niepublikowanego opowiadania pt. Tenshi ${ }^{3}$, napisanego przed właściwym debiutem, najprawdopodobniej w 1946 roku na statku w czasie repatriacji Abe z Mandżurii.

Opowiadanie to przedstawia chorego psychicznie bohatera, przeżywającego niepokój i lęk (jap. kongenteki na kyōki), w końcu przeistaczającego się w anioła, który ucieka ze szpitala i błąka się po kraju aniołów, czyli po świecie, w którym aniołami wydają się i pielęgniarze, i przechodnie. Po prostu, świat poza murami szpitala jest dla bohatera światem anielskim. Opis jego błąkania się po heterotopii zapoczątkowuje serię motywów często wykorzystywanych w późniejszej twórczości Abe Kōbō. Dlatego odnalezione opowiadanie jest ważne dla zrozumienia całej twórczości pisarza, który już w dwudziestym drugim roku życia miał chyba ukształtowane poglądy i wierzył w znaczenie, i moc sztuki. Nie opisywał w sposób realistyczny katastrofalnych warunków panujących na statku repatriantów, a raczej głosił pochwałę życia ${ }^{4}$ (jap. seimei e no kōtei), posługując się groteską i paradoksem ${ }^{5}$.

Paradoks, w którym izba chorych jest więzieniem, a jednocześnie jest bezkresnym kosmosem, znajduje rozwinięcie w krótkiej powieści, wyróżnionej później (1951) Nagrodą Akutagawy, a mianowicie w Kabe - S. Karuma shi no hanzai (Ściana - Zbrodnia pana S. Karmy), w której bohater budzi się rano i nie wie, kim jest. Nie zna swego nazwiska, a w pracy nazywają go panem Karmą, określając jego tożsamość imieniem oznaczającym buddyjską karmę, czyli sumę uczynków decydujących o istocie nowego wcielenia, a w sensie ogólniejszym - grzech pierworodny.

2 Mowa tu o pisanych przez Abe Kōbō w 1947 roku ponad 30 listach do brata studiującego medycynę. W dwudziestym drugim roku życia twierdził, że nic dla niego się nie liczy tylko sztuka, ale bratu radził, żeby koniecznie skończył medycynę.

Z b. "Abe Kōbō sanjūsū tsū no tegami sōsaku e no omoi chokusetsu ni otōto kiou sugata mo" (Ponad 30 listów Abe Kōbō, pragnienie twórczości i entuzjastyczne poparcie dla młodszego brata). MSN sankei nyūsu. 2013. Web. 29.05.2013 <http://sankei.jp.msn.com/life/news/130529/art13052907 470004-n1.htm>

${ }^{3}$ Opowiadanie znalezione w domu lekarza Imury Shunkō w Sapporo, młodszego brata pisarza.

4 Zob.: Katō K. „Kaisetsu” (Komentarz/ Posłowie) do: Abe K. „Tenshi” (Anioł). Shinchō 12 (2012). S. 23.

${ }^{5}$ Opowiadanie Tenshi Abe Kōbō opublikowano w grudniowym numerze miesięcznika „Shinchō” 2012 wraz z posłowiem znawcy twórczości Abe Kōbō, krytyka Katō Kōichi. O nastroju tego pierwszego opowiadania decyduje groteskowy komizm, co można również powiedzieć o stylu ostatniej powieści. 


\section{Kangurowy notatnik - droga od modernizmu do postmodernizmu}

Zastanawiając się nad twórczością Abe Kōbō z perspektywy ostatniego dwudziestolecia, należy, jak sądzę, podjąć próbę kategoryzacji powieści, opowiadań i dramatów, które za życia ich autora znajdowały się w centrum zainteresowań krytyki, jak również czytelników.

W Kobiecie z wydm i w Czwartej epoce (Daiyon kanpyōki, 1959) czy Schadzce (Mikkai, 1977) samotny bohater walczy często z nierozpoznanym wrogiem, prawdziwym lub wyimaginowanym, może $\mathrm{z}$ fatum, i nie godzi się na swój los, nie chce poddać się temu, co go otacza i co go zniewala. Typowy bohater (nauczyciel, sprzedawca butów, pracownik jakiejś firmy) z powodu drobnego błędu w swym postępowaniu jest przenoszony $\mathrm{w}$ nową sytuację, najczęściej potencjalnie groźną. Wtedy rozważa od nowa swe położenie, kalkuluje, formułuje hipotetyczny cel prowadzący do rozwiązania problemu. Czyni to metodycznie, wciąż zmienia środki działania, ale często problem się wikła, staje się coraz mniej zrozumiały i rodzi nowe przeszkody. W końcu bohater godzi się z sytuacją, w jakiej się znalazł, czuje się psychicznie pokonany i niezdolny do przeciwstawiania się nowym utrudnieniom. I tak pogrąża się w świecie, który często traci również własne podstawy. Wciąż poddany jest zagrożeniom, z którymi stara się walczyć samotnie o sprawiedliwość.

Tak uformowany bohater wyrasta $\mathrm{z}$ europejskiej tradycji modernistycznej6, pozbawionej zaściankowości, konserwatywnych zwyczajów, a w związku z tym wszelkiego rodzaju uroków japońskości.

Spośród dzieł Abe najbardziej znana jest Kobieta $z$ wydm, chociaż po polsku ukazały się jeszcze Czwarta epoka (Daiyon kanpyōki, 1959) i Schadzka (Mikkai, 1977). W przekładzie na język angielski dostępne są także powieści Hakootoko (The Box Man, 1973), Hakobune Sakuramaru (The Ark Sakura, 1984) oraz Kangarū nōto (Kangaroo Notebook, 1991). Wszystkie są nowatorskie, awangardowe i w tym ogólniejszym sensie są modernistyczne. Jednak w całej twórczości można wykryć sytuacje, motywy i wątki istotne również dla powieści postmodernistycznej

${ }^{6}$ Tym terminem posługuję się w znaczeniu tendencji nowatorskiej, awangardowej, odrzucającej tradycje rodzime i ograniczenia konserwatywne i zaściankowe. Jako rozległa formacja od końca XIX wieku po lata 60. XX w. charakteryzuje się wrażliwością na problemy społeczne i polityczne, kreowaniem wielkich bohaterów, podejmowaniem ważnych problemów, a zwłaszcza zagrożeń, jak też kultywowaniem indywidualizmu i wolności (zob. G. Gazda. Stownik europejskich kierunków i grup literackich XX wieku. Warszawa: Państwowe Wydawnictwo Naukowe, 2000. S. 312). W Japonii kształtuje się w latach 20. i 30. XX w., i ma kontynuacje po 1945 roku, zwłaszcza w szkole sengoha.

${ }^{7}$ Postmodernizm jako formacja artystyczno-kulturowa kształtuje się od lat 60. XX w. w Stanach Zjednoczonych, później w Europie. Ogólnie można powiedzieć, że wyrasta z modernizmu, pozbywając się aspiracji społeczno-politycznych. Pisarze zaliczani do postmodernizmu w poszukiwaniu oryginalności chętnie przyjmują swobodną postawę wobec stylu i innych technik warsztatowych, intertek- 


\section{Pisarstwo Abe w konteście postmodernistycznym}

W Kangurowym notatniku odnajdujemy właściwie sumę stosowanych wcześniej przez Abe - zarówno w prozie, jak i dramatach - technik i konwencji, które należą do chwytów typowych dla literatury postmodernistycznej. Do tego rodzaju chwytów należą absurdalne toposy, jak na przykład mieszkanie w kartonie (Hakootoko - Mężczyzna w pudełku), eskapizm bohaterów (Kobieta z wydm, Moetsukita chizu Spalona mapa, 1967), senne fantazje (Żotnierz ze snu - Yume no heishi, 1957, Sora o tobu otoko - Mężczyzna latający po niebie, 1975), przemieszanie faktów i fikcji (Życie poety - Shijin no shōgai, 1951, Dendrocacalia - Dendrokakariya, 1949, Mężczyzna, który przemienił się w pałkę - Bō ni natta otoko, 1969). Natomiast wykorzystanie formuł literatury popularnej, fragmentaryzacja struktury bohatera, utrata przez niego wielkich, szczytnych celów i hybrydyzacja, rozbijanie narracji na ulotne skupiska językowych elementów jest już cechą przede wszystkim Kangurowego notatnika. Przyjrzyjmy się więc bliżej tej oryginalnej, ale i dziwnej powieści.

W Kangurowym notatniku bezimienny bohater, człowiek zwyczajny, przeżywa sytuacje zabawne, irytujące i przerażające. Kiedy rankiem odkrywa swędzenie goleni i dostrzega, że coś z niej wyrasta, udaje się do lekarza dermatologa. Odprawiony przez lekarza mężczyzna, umieszczony na szpitalnym łóżku z kołami o własnym napędzie, rozpoczyna wędrówkę do "piekła” - bo tak się rzeczywiście często nazywa gorące źródła. I odtąd jest wożony po labiryncie podziemnego miasta, spotyka lekarzy, duchy, między innymi własnej matki, jak też Amerykanina Hammera Killera, który robi film pt. Fatalny wypadek. Bohater porusza się więc wśród fantasmagorycznych i groteskowych scen, prowadzi nonsensowne dialogi z przypadkowymi osobami. Trudno się czytelnikowi zorientować w chaosie zdarzeń, konwencji, realności i mityczności. Stopniowo jednak zaczynają się one łączyć w całość tematyczną i kompozycyjną. Spoiwem staje się paradygmat ryzykownej, niebezpiecznej podróży bohatera poszukującego skarbu lub utraconego rodzinnego miejsca ${ }^{8}$.

stualnie wykorzystują tradycję ludyczności, w ten sposób niwelując granicę między sztuką wysoką i niską. Do cech zasadniczych postmodernizmu zaliczyć można autorefleksyjność, przemieszanie faktu i fikcji, hybrydyzację, fantazję, humor i ironię (wg Hassana, zob. Gazda 506). Zatem literaturę zaliczaną do postmodernizmu cechuje: intertekstualność (dialog z tradycjami), autotematyzm, antymimetyzm, wykorzystywanie formuł literatury popularnej łączonej z wartościami elitarnymi (wszystko jest dozwolone, bo wszystko już było i nic nowego nie można wymyślić). W postmodernizmie narracja traci wielkiego bohatera, wielkie zagrożenia, wielkie przedsięwzięcia i wielki cel. Zob. też D. W. Fokkema. Historia literatury, modernizm i postmodernizm. Warszawa: Instytut Kultury, 1994, i Ryszard Nycz (red.). Postmodernizm. Antologia przekładów. Kraków: Baran i Suszczyński, 1997.

8 O problemach tej powieści mówiła jej tłumaczka na język angielski podczas konferencji poświęconej Abe Kōbō w Nowym Jorku w 1996 roku, w której autor tego artykułu brał udział (The International Kōbō Abe Commemorative Symposium, Columbia University, New York, April 19-21, 1996). Zob. też 
Odzyskanie utraconego miejsca oznaczać może przywrócenie tożsamości i powrót do społeczeństwa. Byłoby to działanie typowe raczej dla działań modernistycznego heroizmu. $W$ tej powieści bohater wciąż się napotyka na sytuacje absurdalne i niepojęte. Jako człowiek całkowicie ubezwłasnowolniony i manipulowany nie jest świadomy celu, do którego wiedzie go bliżej niezidentyfikowana siła. Przeżywa „przygody” rzadko występujące w powieściach modernistycznych. Większość z nich można odczytać jako parodię przygód tradycyjnych powieści, sugerujących, że natura człowieka jest nieprzewidywalna. Nie tylko natura człowieka, ale także świat, w jakim żyje.

Wyliczając główne zdarzenia opisane $\mathrm{w}$ tej powieści, można przybliżyć świat, w jakim żyje bohater po odkryciu hybrydycznego zjawiska, od którego wszystko się dla niego zmieniło. Oto główne „zdarzenia”:

1) przebudzenie się bohatera i odkrycie nienormalności, czyli braku zwyczajowej codzienności, zaskakującej bohaterów we wcześniejszych powieściach Abe;

2) spotkanie $\mathrm{z}$ kierownikiem $\mathrm{w}$ pracy, aby przedyskutować pomysł na produkt o nazwie "kangurowy notatnik";

3) wizyta u lekarza i spotkanie z pielęgniarką wyjątkowo niesympatyczną, którą przezywa Tombo Megane, czyli Ważką Okularnicą;

4) zakłopotanie lekarza, który nie chce się zajmować podejrzaną chorobą, więc kieruje pacjenta do ciepłych źródeł;

5) przywiązanie bohatera do łóżka o własnym napędzie i ekspediowanie go do Piekielnej Doliny;

6) uwięzienie w kanałach pod miastem;

7) dotarcie do źródeł siarkowych (do „piekiełka”) i spotkanie w piekle mitycznych dzieci-demonów nad rzeką Sainokawara w otchłani daremnych wysiłków;

8) spotkanie ducha matki i Hammera Killera uprawiającego karate, wróżącego i leczącego choroby;

9) leczenie przez Hammera prowadzi bohatera do nowej choroby, dlatego zostaje on skierowany do szpitala, gdzie odzyskuje swoje magiczne łóżko;

10) wyprowadzenie $z$ podziemi przez pielęgniarkę;

11) przyjazd na opuszczony dworzec kolejowy i zniszczenie łóżka przez nadjeżdżający pociąg;

12) romans z molestującą go kobietą, co jest raczej parodią romansu.

Powieść kończy się przytoczeniem fragmentu artykułu z gazety na temat odkrycia ciała mężczyzny na opuszczonym dworcu kolejowym. Na jego goleniach dostrzeżono szramy po ciętych ranach.

K. Abe. Kangaroo Notebook. Tłum. Maryellen Toman Mori, Alfred A. Knopf. New York: Afred A. Knopf, 1996. 
Z długiej listy motywów wynika, że mimo dotarcia do leczniczych źródeł, bohater nie zostaje uleczony i nadal jest hybrydowym tworem, zepchniętym na margines społeczny.

Można też uznać, że droga, jaką mężczyzna odbył, składała się głównie z trawestacji opowieści o bezskutecznym poszukiwaniu sensu egzystencji. Podróż ta nie przynosi więc ulgi: bohater nie może poradzić sobie $\mathrm{z}$ chaosem otaczającej go rzeczywistości. Co prawda spotyka skądś znane sobie postaci i sytuacje, ale sens tych zdarzeń pozostaje niepojęty. Podjęty bowiem przez bohatera wysiłek poszukiwania sensu jest syzyfowy, bo nikt mu nie może lub nie chce pomóc, każdy kieruje się własnym interesem. Wszyscy, którzy powinni dać mu poczucie bezpieczeństwa, zawodzą. Opowieść przypomina raczej parodię podróży heroicznej. Można ją traktować również jako próbę stworzenia metafory losu ludzkiego.

Kangurowy notatnik niewątpliwie wzbogaca nurt japońskiej fantastyki i wizji utopijnej, do których należą takie utwory, jak Kappy (Kappa) Akutagawy Ryūnosuke (1892-1927), chociaż mamy tu do czynienia z dystopią, swego rodzaju antyutopią, podobnie jak w Schadzce i Czwartej epoce ${ }^{9}$.

W rozdziale trzecim Kangurowego notatnika zatytułowanym „Rzeka ognia” czytamy:

Ściany kanału zwęziły się. I ukazała się goła skała z widocznymi śladami ręcznego skuwania. A nurt znacznie przyspieszył.

Droga wodna załamała się pod kątem prostym i rozszerzyło się pole widzenia. Okropna woń. Chmura pudru taniny. Rozdyma błonę śluzową w nosie. I nagle oślepiający błysk latarni. $\mathrm{W}$ pociemniałym polu widzenia zaiskrzyło się koryto rzeki.

Czy umarłem? I jako umarły w końcu dotarłem do tamtego świata? Poczułem narastający smutek. Gdy ścisnąłem nos palcami, z ust popłynął refren melodii bez sensu.

Hanakonda, aragonda, anagenda

Posmaruj olejem pieprzowym

I owiń skórką banana.

To refren pieśni „Zapadła noc na Drodze Taniny”. Droga Taniny krzyżuje się z Drogą Jedwabną. To droga, którą przewożono herbatę.

Anabenda, anakonda, anagenda

Rufa podskoczyła. Łódź wpadła do basenu wodospadu. To pewnie moje złudzenie. Kanał, którym płynąłem, znajdował się w pobliżu ujścia rzeki, na poziomie morza. Nie mogło tam być wodospadu niżej od morza.

Czy po prostu spadłem na dno ziemi? Czy to już piekło?

Skała otarła się o dno łodzi. Czy raczej dno łodzi otarło się o skałę.

Osiedliśmy na mieliźnie.

9 Zob. M. Melanowicz. Japońskie narracje. Studia o pisarzach współczesnych. Kraków: Wydawnictwo Uniwersytetu Jagiellońskiego, 2004. S. 168. 
Łódź rozpadła się i odpłynęła. Pozostało tylko moje łóżko, stojące na brzegu rzeki. (Abe 1991: 66) ${ }^{10}$

W ten sposób w szybkim tempie bohater zbliżył się do celu, w którym ma być poddany leczeniu w gorącym, siarkowym źródle. Następuje rozdział czwarty pt. „Córka Drakuli”, następnie kolejno rozdziały pt.: „Propozycje nowego systemu ruchu drogowego" (piąty), „Pieśń wiatru” (szósty) i „Porywacz ludzi” (siódmy).

Pociąg już zwolnił bieg, uderzenie było więc łagodniejsze niż się spodziewałem, ale różnica ciężaru między obu przedmiotami była wielka. Moje łóżko zaczęło skręcać się z bólu i krzyczeć patetycznie, aż się rozpadło na oczach, zamieniając w kupę złomu. Magiczny dywan rozleciał się na kawałki. Cykliczna opowieść ostatecznie się skończyła. Czy to jest dla mnie koniec tej drogi? Dotąd za każdym razem, gdy się znalazłem na krawędzi katastrofy, łóżko zawsze mnie ratowało, budząc mnie z jednego snu i wprowadzając w drugi... (Abe 1991: 194) ${ }^{11}$

Tak więc kanałami pod miastem mężczyzna dopływa do piekła Sainokawara, przeżywa zdarzenia jak z koszmarów sennych. Na opuszczonej stacji kolejowej spotyka czarującą dziewczynę, rozbudzającą tęsknoty za czymś już nieosiągalnym. Wtedy budzi się jakby ze snu. Dowiaduje się, że dziewczyna czeka na przyjazd cyrku, wraz z którym ma się pojawić „porywacz”. Pobrzmiewa muzyka, dziewczyna śpiewa. Wtedy pojawiają się jakieś diabełki, rozlega się głos wołający o pomoc, a bohatera kryją w kartonowym pudle, z którego obserwuje on świat przez dziurkę. Patrzy też na zalęknionego siebie samego.

W przytoczonym na końcu powieści fragmencie artykułu z gazety jest mowa o zmarłym mężczyźnie, na którego nogach są ślady ran zadanych żyletką, ale jego tożsamości jeszcze nie stwierdzono.

W całej powieści wyczuwalne są obrazy śmierci, chociaż notatki na różne tematy prowadzone są lekko, bez poważnych rozważań. Można jednak przypuszczać, że pisał je człowiek już schorowany, zagłuszający ból muzyką. Nie skarżył się bliskim i znajomym ze swych dolegliwości. W Notatniku kangurowym przedstawił ostatnią podróż w nieznane, jako drogę łączącą świat rzeczywisty z fikcyjnym, z podziemnym, parodiując przygodowe opowieści i wyobrażenie o zaświatach. Przedstawił je za pomocą rozsypanych obrazków, hybrydycznych sytuacji typowych dla narracji postmodernistycznych. Stworzył bohatera o tożsamości niespójnej, żyjącego bez celu, bohatera niezdolnego do walki ani o sprawiedliwość, ani nawet godne miejsce dla siebie. Może tylko pomysł stworzenia „kangurowego notatnika”, pomysł nieprzemyślany, wrzucony do skrzynki pomysłów w zakładzie pracy, zacznie symbolizować jego niespełnione zamiary, jego marze-

\footnotetext{
10 Tłumaczenie własne.
}

11 Tłumaczenie własne. 
nia. Wyrażenie „kangurowy notatnik" pojawia się wielokrotnie w jego pamięci. $\mathrm{W}$ ostatnim rozdziale na pytanie Studenta, czym się zajmuje w pracy, potrafi powiedzieć jedynie, że miał stworzyć nowy produkt dla swej firmy i że to miał być „notatnik kangurowy”, i wtedy rozpoczyna rozmowę na temat kangurów raczej, a nie pomysłu, który jeszcze nie dojrzał, nawet gdy pomysłodawca wędrował przez piekło. I przeczuwał zbliżający się koniec.

Timothy Iles, autor książki na temat twórczości Abe Kōbō, sugeruje, że tematem tej powieści jest śmierć, do której człowiek bezwolnie zmierza, mając jeszcze przebłyski nadziei na powrót - choćby na krótką chwilę - do normalności, albo nawet do kraju dzieciństwa, w którym przecież nie było porozumienia, nie było intymności między nim a rodzicami, a więc żadnej idylli, za którą dziś tęskni (Iles 95). I nie wie, jak skończy. W tej powieści znajdą go ludzie na jakimś opuszczonym dworcu kolejowym, jako bezimiennego martwego już wędrowca.

\section{BIBLIOGRAFIA}

Abe, Kōbō. Kangaroo Notebook. Tłum. Maryellen Toman Mori, Alfred A. Knopf. New York: Afred A. Knopf, 1996.

Abe, Kōbō. Kangarū nōto (Kangurowy notatnik). Tōkyō: Shinchōsha, 1991.

Iles, Timothy. Abe Kobo - an Exploration of his Prose, Drama and Theatre. Fucecchio (Firenze). Italy: European Press Academic Publishing, 2000.

Fokkema, Douwe W. Historia literatury, modernizm i postmodernizm. Warszawa: Instytut Kultury, 1994.

Gazda, Grzegorz. Stownik europejskich kierunków i grup literackich XX wieku. Warszawa: Wydawnictwo Naukowe PWN, 2000.

Katō, K. „Kaisetsu” (Komentarz/Posłowie) do: Abe K. „Tenshi” (Anioł). Shinchō 12 (2012). S. 23.

Melanowicz, Mikołaj. Japońskie narracje. Studia o pisarzach wspótczesnych. Kraków: Wydawnictwo Uniwersytetu Jagiellońskiego, 2004.

Nycz, Ryszard (red.). Postmodernizm. Antologia przekładów. Kraków: Wydawnictwo Baran i Suszczyński, 1997.

\section{Źródło elektroniczne}

"Abe Kōbō sanjūsū tsū no tegami sōsaku e no omoi chokusetsu ni otōto kiou sugata mo" (Ponad 30 listów Abe Kōbō, pragnienie twórczości i entuzjastyczne poparcie dla młodszego brata). MSN sankei nyūsu. 2013. Web. (29.05.2013) <http://sankei.jp.msn.com/life/ news/130529/art13052907 470004-n1.htm> 